\title{
Image Re-branding in a Fragile State: The Case of Nigeria*
}

\author{
Godwin Uyi Ojo** and Iro Aghedo***
}

\begin{abstract}
In today's globalized world, nations are increasingly concerned about how they are perceived by their publics, often carefully planning and executing policies to maintain a positive identity or shed a negative image. While some countries are able to execute nation branding, others are not. Using the Nigerian experience as a case study, this article shows how the character of a state can undermine its capacity for successful nation branding. We argue that countries are judged not just by what they say but also by what they do, and that inherent contradictions such as sectarian violence, ethnic tension, and corruption underline Nigeria's underdevelopment and its reputation at home and abroad. We assess this trajectory in the context of state fragility and "prebendalization" politics in a country with a powerful colonial legacy, and suggest a duality of order and disorder involving formal and informal structures of governance that impinge significantly on re-branding efforts.
\end{abstract}

Keywords: Nigeria, fragile state, corruption, violence, re-branding

* The authors wish to acknowledge the three anonymous reviewers for their insightful comments.

** Godwin Uyi Ojo is a lecturer in the College of Arts and Social Sciences, Igbinedion University, Okada, Nigeria, and executive director of Environmental Rights Action/Friends of the Earth Nigeria. He received a PhD from King's College, London. E-mail: Gloryline2000@ yahoo.co.uk.

*** Iro Aghedo (corresponding author) is a lecturer in the Department of Political Science, University of Benin, Benin City, Nigeria. He was educated at the universities of Ibadan and Benin in Nigeria and at the School of Oriental and African Studies, University of London. His articles have been published in the Review of African Political Economy, African Security, Journal of Asian and African Studies, and Third World Quarterly, among others. E-mail: matthew.aghedo@uniben.edu.

Manuscript received May 5, 2013; out for review May 25, 2013; review completed August 6; accepted August 8, 2013.

The Korean Journal of Policy Studies, Vol. 28, No. 2 (2013), pp. 81-107.

(C) 2013 by the GSPA, Seoul National University 


\section{INTRODUCTION}

Since the late 1970s, successive Nigerian governments have engaged in nation branding aimed principally at shedding the country's negative image domestically and internationally. Aside from being the most populous black nation in the world, with over 160 million people, Nigeria is also generously endowed with oil, gas, and other natural resources, making it strong ally in global economic relations. It ranks among the seventh largest oil exporters in the world. However, the hope that the country's enormous human and material capital would translate into considerable influence in international affairs has remained elusive largely because of its negative image.

Nation branding is crucial in the current global order because it enhances public diplomacy, global socio-economic competitiveness, and soft-power promotion (Ham $\&$ Jun, 2008). The image and reputation of a country can attract both tangible and intangible benefits, including tourism revenue, investment capital, and foreign aid, and can boost its cultural and political influence in the global arena. Accordingly, there has been increasing awareness in recent years that the reputation of a country, city, or region behaves rather like the brand image of a product or company and is crucial to its progress and prosperity (Anholt, 1998).

In recognition of this, many countries formulate policies aimed at positively influencing global perceptions in order to realize the economies of scale that accrue from the production, distribution, and marketing of outputs in the global market. This quest for global competitiveness underpins China's Shanghai Expo and its production of promotional films to boost its international image using domestic cultural revitalization as a springboard for soft power (Barr, 2012). Also, through careful nation branding, Spain - which was isolated and poverty-stricken in the Franco era-has emerged as a modern European democracy and first-choice tourist destination (Gilmore, 2002). Branding has also made Japan famous for technology, Paris for style, Switzerland for wealth, and Rio de Janeiro for carnival. Yet, much of Africa is notorious for corruption, poverty, conflict, disease, and weakness of public institutions.

The Nigerian public space and discourse have been replete with re-branding initiatives since the Jaji Declaration by the Obasanjo military government (1975-1979). Shortly after the Shagari-led civilian interlude, the Buhari/Idiagbon regime (19831985) launched the War against Indiscipline (WAI) campaign. This was followed by the MAMSER and Not in Our Character initiatives, promoted by the Babangida and Abacha dictatorships, respectively (1985-1998). The return to civil rule witnessed a revamping of image laundering in the country as exemplified by the Heart of Africa and Image Re-branding policies of the Obasanjo (1999-2007) and Yar'Adua (20072010) administrations, respectively. The Image Re-branding project was the most 
comprehensive and expensive nation-branding initiative yet. It had the motto "Nigeria: Good People, Great Nation" and was aimed at "accelerating Nigeria's development through foreign investment and tourism" (Albert, 2009, p. 406).

But despite over three decades of re-branding efforts, Nigeria's image has remained "an insignia of dishonest, dishonour, and disrespect" (Bamiduro \& Aremu, 2012, p. 11). A fervent journalistic blitz to sway public perception has hardly resulted in any meaningful improvement. Levels of crime and insecurity are high, and corruption remains endemic - though increasing global insecurity may suggest that crime and corruption are not peculiar to Nigeria. According to Akunyili (2009a, p. 1), "corruption and bad behaviour are not only domiciled in Nigeria and Nigerian blood but are pervasive all around the world." Indeed, in the United Kingdom, United States, and Russia, among other western countries, street urchins and gun-carrying youths have unleashed terror that has claimed several lives in gang wars that leave many bewildered (Foley, 2009). State responses to step up security and social security measures to abate the crime have been the norm.

In pursuit of the Image Re-branding project, the Federal Ministry of Information and Communication requested 320 billion Nigerian naira (\#) in 2010, a steep increase over the 150 million approved for the project in 2009 (150 is equivalent to about US\$1). Questions were asked about whether the huge sums of money would be used to "re-brand" some private pockets, as had happened in other programs in the past. Against the journalistic blitz to correct Nigeria's image, it is pertinent to ask: what is responsible for Nigeria's image collapse? And why have previous rebranding efforts been ineffective? Grappling with these questions is vital not only to Nigerians and their governments, who deserve to know why their nation's image is so negative and why enormous revenues are spent on ineffective campaigns, but also to other countries and their citizens, who relate with Nigeria as aid donors, business people, and tourists, and in other ways.

This article explores the politics underpinning the re-branding project and assesses it as rhetoric that seems to deny reality. The following sections lay the conceptual and theoretical groundwork for the analysis, discuss the relevance of re-branding to Nigeria, summarize the country's positive and negative characteristics, and then draw conclusions and emphasize the need for structural and attitudinal changes in the country.

\section{CONCEPTUALIZING NATION BRANDING}

The term brand can be used in three senses: to describe the designed identity of a product, to refer to the culture of the organization behind the product, and to approximate 
the product's or corporation's reputation in the minds of its target audience (Anholt, 1998). Branding is a tool of marketing in which a new name, term, symbol, design, or a combination of these is created for a product with the aim of developing "a new differentiated identity in the minds of consumers, investors, and competitors" (Muzellec \& Lambkin, 2006, p. 803). According to the Committee on Re-branding (2009, p. 1), a brand is "the totality of consumers' experience, perception, benefits and values." Customers' perception of a brand matters a great deal to the brand owner. This explains why a brand image is carefully built, "maintained and positioned" (Stobart, 2002, p. 63).

Though the term brand is often used in relation to products, it has recently been applied to countries (nation branding), as the Nigerian, Korean, Chinese, and American re-branding projects demonstrate. Nation branding has been defined as "the strategic self-presentation of a country with the aim of creating reputation capital through economic, political and social interest promotion at home and abroad" (Szondi, 2008, p. 5). This may stem from self-defense, as when a country tells its own story in contradiction to foreign media portrayals, definitions by rival nations, or the perpetuation of national stereotypes (Dinnie, 2008). For example, a Presidential Council on Nation Branding was established in South Korea in 2009 by President Lee Myung-Bak, who had taken exceptional interest in improving the international perception of the country. Also, since the US "War on Terror" response to the September 11, 2001 attacks, the name America has become largely circumspect, especially in the Islamic world, because of an alleged American imposition of its brand of liberal democracy that many believe is underpinned by the desire for access to oil in Iraq and elsewhere (Maass, 2009; Keen, 2006). The US image declined during this period, but for a new re-branding for change signaled by President Barrack Obama.

Nation branding differs from product branding because the parameters for the former are far more intricate and they take considerable time to manifest. Such parameters include domestic social, economic, and political well-being. Therefore, re-branding a nation without proper governance is like putting the cart in front of the "social transformation" horse (Albert, 2009, p. 432). The corporate reputation which re-branding engenders often enhances, regains, transfers, and/or recreates the corporate brand equity (Muzellec \& Lambkin, 2006). It is often driven by internal and/or external factors. Nevertheless, it is not a magic formula, because to distil the vastness of a country's national identity into something relevant and communicable to distinct audiences is often very challenging. Whether in nations, organizations, or individuals, reputation can be observed from behavioral patterns (Bryant, 2005). 


\section{THEORIZING STATE FRAGILITY IN AFRICA}

Nigeria's reputation is at its lowest ebb. Some social critics describe Nigerians in general terms as criminally minded. For example, former US Defense Secretary Colin Powell once referred to Nigeria, in reaction to the pervasiveness of Internet fraud in the country, as "a nation of scammers" (quoted in Glickman, 2005, p. 461). Such sweeping statements over-generalize, yet there is some truth in what others see as a few bad apples in the basket. The character and nature of the Nigerian state provide a vital aperture for a proper understanding of the country's image crisis.

Scholars have noted that African statehood is not only engrossed in internal conflicts but is also unable to break free from postcolonial legacies (Collier, 2007; Herbst, 2000; Reno, 1998). It is widely agreed that the postcolonial state in Africa is fragile and therefore largely unable to effectively discharge its statutory responsibilities, such as protecting lives and property and meeting the welfare and development needs of the people (Osaghae, 2007; Young, 2004). Bifurcated by the colonial situation, African states were characterized by both centralized and decentralized forms of despotism in ways that racialist ideology and practice had far-reaching implications for the relations between citizens and subjects (Mamdani, 2002). Such a legacy of state fragility in Africa is often attributed to poor institutionalization, which makes public institutions to thread both formal and informal paths (Joseph, 2002).

The criminalization of African states assumes wider dimensions within colonial discourse and the character of the states. Since the 1950s, scholars' attention has focused on decolonization in relation to ethnicity and conflict involving peace, development, and governance (Pottier, 2010). In Asia, Latin America, and Africa, the extant postcolonial states are seen largely as prototypes of the colonial empires which, under the pretense of development, carted away natural resources to build their empires, thereby initiating

a false start in Africa development (Arrighi, 2002; Dumont, 1988). Colonialism also brought a new form of political order and its hegemonic economic structure of neoliberal capitalism and wealth accumulation, which displaced traditional means of governance. Colonialism helped the "curtailment of communal and individual freedoms" and a paternalistic reordering of a people's cultural nexus as a coercive instrument of state (Nduka, 2006, p. 8). While this suggests "Western ethnocentric arrogance," yet, the new elites displaced the colonial masters and took over the reins of nation building but without letting go of an ingrained colonial mentality (Nduka, 2006, p. 6). Mirroring the old feudal system in a new political order that promises better life and freedom became the new vogue at independence.

In Africa, this new culture of modernity and development was built on faulty fissures of amalgamation of differing nationalities, tribes, and tongues. This cultural collapse 
in the face of culture clash, as in sub-Saharan Africa, remains the challenge of national unity and nation building. Following the amalgamation of ethnic groups by Lord Lugard, Nigeria became a colony of the British Empire in 1914 with over 350 ethnic groups (including Hausa-Fulani, Igbo, Yoruba, Ijaw, and Edo) and 300 languages, which make ruling and coordination of the various groups for national identity and development an uphill task. For example, due to ethnic distrust and fear of domination, Nigerians have no need for a mother tongue lingua franca apart from the language of the British colonizers. Although some scholars do not see any appreciable link between "ethnic and religious fractionalization" and conflict (Collier, 2000, p. 108; Oyefusi, 2008), the case of Nigeria seems to suggest the contrary. Indeed, the more there are heterogeneous enclaves of diverse people in a country, the more the potential for sectarian violence and disorder (Svensson, 2007).

It is not surprising that some scholars suggest the criminalization of the African state in manners that denote "disorder as a political instrument" that maintains the elites in office (Chabal \& Daloz, 1999). True, primordial sentiments such as ethnicity and religion are manipulated by the elites in pursuit of personal and sectional agendas, leading to a culture of corruption, patron-clientelism, and prebendalism (De Oliveira, 2007). The term prebendalism was used by Joseph (1987) to denote a form of patronclientelism in Nigeria whereby state officeholders appropriate and use public resources to generate private material benefits for themselves and their constituents. This suggests that both the formal and informal structures of governance that are inevitably in apposition nevertheless buoy the system that allows "spoils politics," insecurity, and corruption as part of the institutionalized means of governance (Allen, 1999, p. 372; Smith, 2007). These historical antecedents combined with the challenge of modern statecraft help in making sense of state fragility and behavior that undermines national integrity and reputation, which re-branding is meant to address.

As part of the colonial legacy, several African nationalists also mobilized the people for independence from the colonialists on the basis of anti-state campaigns. Both leadership and followership remain problematic in the African state project, though the pervading practice is to blame only the leaders. The state is not only colonial in nature but also largely fictional in the minds of citizens. Conceived as an alien institution, plundering the state for parochial interests was seen as a virtue rather than a vice. Public service under colonial rule in Igboland was largely externalized as olu oyibo (the white man's job) (Osaghae, 2002). Having been internalized, these negative perceptions remain pervasive and continue to structure and condition the attitude of both rulers and ruled (Utomi, 2004). Therefore, the continuation of the colonial legacy in Nigeria is largely a result of governance crisis.

State fragility does not have a generally acceptable characterization. However, 
Osaghae (2007, p. 693) itemized the basic features of fragile states thus:

1. Weak, ineffective, and unstable political institutions and bad governance, conducive to loss of state autonomy; informalization, privatization of state, personal and exclusionary rule; neo-patrimonialism; and prebendal politics.

2. Inability to exercise effective jurisdiction over its territory, leading to the recent concept of ungoverned territory.

3. Legitimacy crisis, occasioned by problematic national cohesion, contested citizenship, violent contestation for state power, perennial challenges to the validity and viability of the state, and massive loss and exit of citizens through internal displacement, refugee flows, separatist agitation, civil war, and the like.

4. Unstable and divided population, suffering from a torn social fabric, minimum social control, and pervasive strife that encourage exit from rather than loyalty to the state.

5. Underdeveloped institutions of conflict management and resolution, including credible judicial structures, which pave the way for recourse to conflict-ridden, violent, non-systemic and extra-constitutional ways in which to articulate grievances and seek redress.

6. Pervasive corruption, poverty, and low levels of economic growth and development, leading to lack of fiscal capacity to discharge basic functions of statehood, including, most importantly, obligations to citizens such as protection from diseases like AIDS and guarantees of overall human security.

To a large extent, Nigeria exemplifies the paradox of the postcolonial state in Africa, where the relevance of the state diminishes every day. Nigerians carry on as if the state does not exist - they build their own houses, provide their own private security, build their own roads, and sink their own boreholes (Amuwo, 2009; Lewis, 2004; Ihonvbere, 1994). These internal contradictions of the Nigerian state with scanty means for survival lead to despondency and low morale. The army of unemployed youths takes advantage of the opportunity for rebellion and violence against the state and other antisocial behavior such as armed robbery, cultism, and a growing kidnapping enterprise (Osumah \& Aghedo, 2011; Onovo, 2009; Awah, 2009). Hence, for both rulers and ruled, disorder is more than a "political instrument" that highlights the criminalization of the state and in ways that allow the formal means of governance to run side by side with the informal (Bayart, et al. 1999). By assessing these formal and informal means, the authors make a modest contribution to the literature and in understanding the contradictions of re-branding in a weak state in relation to its value system. 


\section{WHY RE-BRANDING IN NIGERIA?}

That Nigeria is in dire need of re-branding is not in doubt. It is needed not only to correct misconceptions about the Nigerian state but to showcase its contributions and achievements on a global scale. It aims to instill confidence among citizens and present rebuttal arguments against erroneous claims. The former Minister of Information and Communication, Professor Dora Akunyili, was the architect of the latest re-branding project. She has said in various engagements since March 17, 2009, when the project commenced, that the perception of Nigeria is negative worldwide, as evidenced by the intimidation of Nigerian green passport holders by most foreign immigration personnel. While she blamed this on the behavior of a few Nigerians whose activities undermine the country, she also attributed this image collapse to the negative stereotyping of the country by some foreign media. Therefore, the internal objectives of the re-branding campaign are to reconnect Nigerian people with the Nigerian nation; make Nigerians own and be proud of the Nigerian brand; and re-position Nigeria as a modern, democratic, disciplined, and accountable nation (Committee on Re-branding, 2009). This challenging task aims to make every Nigerian the chief advocate of the Nigerian project through community participation and media re-orientation to project Nigeria in good light.

Externally, the campaign is aimed at changing negative perceptions of Nigeria among foreigners and external stakeholders by leveraging the passion of Nigerians in the diaspora, promoting Nigeria's economy and tourism to make it globally competitive, and addressing media imperialism in all its ramifications (Albert, 2009). It is closely linked with ex-President Umaru Musa Yar'Adua's 7-Point Agenda and the achievement of Vision 20:2020 (Nigeria's goal to be among the 20 most industrialized nations in the world by 2020). According to Akunyili (2009b, p. 1), "Nigeria is waiting to be exploited and developed" by attracting significant foreign investors into the country, which has a "big market and some of the highest returns on investments found anywhere in the world. Such calculations also envisage economic growth that will generate employment and thus "reduce crime and enhance national security" (Ministry of Information, 2009, p. 1).

A logo with the words "Nigeria: Good People, Great Nation" as symbol for the re-branding represented the first achievement for this initiative. As part of its implementation strategy, re-branding clubs have been established in some Nigerian high schools and tertiary institutions with a view to inculcating a culture of civility and patriotism in the students. Nigerian embassies in 105 locations worldwide have also been used for the project, because they represent windows through which the country is perceived. In a globalized world, events in Nigeria and elsewhere can no longer be 
hidden from the eyes of the international community (Scott, 2009).

The campaign also involves state governors, ministers, members of the National Assembly, and ordinary Nigerians who participate in the program through town hall meetings so that they would represent and obtain feedback on government activities. Members of Nollywood (the booming Nigerian home-video industry) have also been wooed to join the re-branding effort because the film-making industry enjoys considerable patronage in Africa and other parts of the world and is seen as possessing the potential to effect social change. Furthermore, several thousands of the National Youth Service Corps members engaged in volunteering social work have been deployed in the implementation of the project (Alao, 2009). Such partnerships with some ministries and institutions are strategic. For example, while the partnering with the National Youth Service Corps is to utilize the over 300,000 graduate corps members spread across the country; the Ministry of Education is targeted to facilitate the establishing of re-branding clubs in schools as part of civic studies in the educational curriculum.

The Ministry of Foreign Affairs, Nigerian embassies abroad, and foreign embassies in Nigeria are targeted by re-branding campaign managers so that the ambassadors could drive the messages to their various countries and to engage over 17 million Nigerians in the diaspora in the campaign. According to Akunyili (2009b, p. 6), the campaign would take the following form:

production and placement of bill boards in strategic locations around the country and outside; the production of collateral package for the re-branding campaign such as T-shirts, face caps, table clocks, mugs, crests, umbrellas; production of different literature on Nigeria that will impact on a positive image; the production of audio visuals such as radio jingles, TV commercials and their placements in the media, locally and internationally; logistic support for the series of town hall meetings in all states of the federation; media package support for comprehensive coverage and interventions. ... We will put up outdoor bill boards in the capital cities of every state, the airports, border towns and other strategic locations in Nigeria; we will set up dynamic websites that will have important and current information about Nigeria; we will identify and use brand icons, individuals that have excelled in their professional fields; we will use institutions like banks and other businesses that have performed creditably as models and brands; and we will showcase our strengths, build upon our areas of success and work on those areas in which the country has clearly failed to perform.

In addition to changing the perception of Nigerians and the international community, the initiative is expected to also re-brand some critical state institutions whose performance could make or mar the image of the nation, including the police force, the civil service, the political leadership, schools and colleges, the rank and file of labor, the 
corporate sector, religious and social institutions, the immigrations and customs service, and all other "reformable institutions whose woeful performances have led the Nigerian people down the path of regrets and aborted dreams" (Akunyili, 2009a, p. 5).

\section{SHOWCASING THE GOOD AND BEAUTIFUL}

Not every fiber of social life in Nigeria is up for re-branding. Not only has the nation achieved some enviable feats, but some individual Nigerians have reached the pinnacle of their professions at the international level. One strategy of the re-branding effort has been to showcase these stories of significant successes.

Nigerians are said to have good survival instincts, to love life, and to be good followers and imitators, be it for good or bad. The name Nigeria is well known worldwide - notably, for its prowess in soccer, having won the Under 17 World Cup in 1985, 1993, and 2007. The country also won the under-23 Olympic Soccer Gold in 1996. Soccer has become a unifying force that cuts across ethnicity and religion, and Nigeria has contributed enormously to global football development.

Nigeria's contributions to United Nations peacekeeping initiatives and the subsequent decorations of Nigerian officers for meritorious service are arguably second to none. The country's peacekeepers have been sent to Bosnia-Herzegovina, Chad, Lebanon, Liberia, Rwanda, Sierra Leone, Somalia, Sudan, and other global hotspots (Okolie, 2010). Between 1960 and 2010, the country committed over 250,000 men and women to support UN peacekeeping operations, "losing 2,000 troops in the process and expending \$10 billion" in spite of its lean resources (Reviewing Nigeria's role, 2010). This has made Nigeria the fourth largest contributor of troops to the United Nations since 1960. As a result, the United Nations has designated the country as a training center for international peacekeeping troops.

Perhaps individual achievements dwarf any national successes, although individuals make up nations. The people of Nigeria, the most populous African nation with emerging markets, are said to be resourceful and enterprising. A Nigerian, Ngozi Okonjo-Iweala, served at the top of the World Bank hierarchy as vice president. Several Nigerians both at home and in the diaspora are excelling in their various professions including Wole Soyinka, who became the first black African Nobel laureate for literature in 1986; Chinua Achebe, another literary icon and author of the legendary novel Things Fall Apart, whose protagonist Okonkwo has become a household name in most parts of the world; Booker Prize winner Ben Okri; the recent rave of the literary world Adichie Ngozi Chimamanda; former Secretary-General of the Commonwealth of Nations Emeka Anyoku; businessman Adebayo Ogunlesi, who recently acquired London 
Gatwick Airport; Victor Oladokun of the Christian Broadcasting Network; and the US-based computer wizard Philip Emeagwali, to name but a few. These achievers show that Nigeria is not all a gory picture of crime and violence but also of creativity, skills, and enduring legacies of universal acclaim.

The Nigerian state through the re-branding project thus subscribes to emulating the exemplary feats of these achievers, if but to stem its poor image. Aside from human endowment, Nigeria is a force to reckon with in global energy because, as a major oil producer, it is first in Africa and a leading member of the Organization of Petroleum Exporting Countries, with a daily production of over two million barrels of oil. In 2007 alone, it supplied " 12 percent of total US crude imports" and also supplied destinations in Europe, making it a reliable partner to them (Watts, 2007, p. 638).

\section{CHALLENGES OF IMAGE RE-BRANDING IN A FRAGILE STATE}

In spite of the success stories described in the previous section, negative trends and crimes attributed to Nigerians have earned the nation a poor image. However, the challenge of re-branding is neither new in Nigeria nor exclusive to it. For example, under British New Labour project, spin doctoring and political sloganeering led to the elevation of governmental "image over substance" in a bid to counter right-wing media criticisms of the Labour Party (Scammell, 1995, p. 4; see also Moloney, 2000). Chile and Angola have also re-branded themselves in a post-conflict era to take advantage of socio-economic restructuring. In such cases, efforts to address the fundamental problems are building blocks for re-branding. Critics of the Nigerian re-branding project have argued that it fails to diagnose and address the root causes of the country's image collapse and seems to focus on treatment of the symptoms rather than the disease.

Re-branding as a response to the armed conflicts over resources in the Niger Delta is limited. Tribal claims to resource ownership are unlikely to respond to the politics of re-branding. That aside, its geo-strategic importance in global energy calculations, and oil revenues that account for about 80 percent of Nigerian government funds, have not resulted in provision of social services for citizens (Aghedo, 2013). Regrettably, the politics spawned by oil wealth imbues the country with the corrosive features of rentierism and the resource curse, such as elite primitive accumulation and its associated political instability (Nwajiaku-Dahou, 2009). National average income has been put at about $\$ 1$ a day and "a fifth of children die before their fifth birthday" (Peel, 2005, p. 2), despite the realization of over $\$ 300$ billion in oil revenues between 1975 and 2004. To the victims of state failure in the face of inadequate social services, re-branding is an exercise in futility. 
More structurally, a major source of Nigerian image collapse is political corruption. As admitted by Akunyili (2009c, p. 1), "right now, the perception of what we have as a brand is a corruption brand, a near collapse state brand, a dysfunctional people brand and a brand that is hard to sell." Since the colonial era, the organization and management of state power have largely been driven by parochial agendas of the ruling elite, often at the expense of citizens' welfare. Although it has been observed that oil-rich countries are prone to war, allegations of corruption during the First Republic were partly responsible for the emergence of the first military coup in 1966, only six years after independence (Osumah, 2013).

The first phase of military rule was vitiated by numerous corruption scandals. For example, an inquiry set up after Gowon's removal from office showed that of Gowon's 12 military governors, only two were innocent of "illegal self enrichment" (Falola \& Heaton, 2008, p. 187). Despite the purge of the public service through the Jaji Declaration aimed at changing the attitude of Nigerians to ensure self-discipline, patriotism, and national cohesion, corruption remained rife. This generalized rot and gross indiscipline were partly responsible for the second military takeover of political power and the introduction of the War against Indiscipline (WAI) by the Buhari/Idiagbon regime. The implementation of the WAI re-orientation policy was far more popular but resulted in the diminution of citizens' human rights. Horsetail whips (known locally as koboko) were used indiscriminately by members of the state armed forces to flog citizens to enforce compliance. Despite gross human rights abuses, the WAI policy was perceived to have achieved some level of cohesion by coercion.

Under the Babangida dictatorship, the concentration of powers gave rise to unprecedented corruption. Even debt rescheduling, servicing, foreign aid, and transition to civil rule were manipulated for self-enrichment (Lewis, 1996). The administration was noted for corruption and yet to account for up to $\$ 12.2$ billion of oil Gulf War windfall (Amuwo, 2009). These were further deepened by his successor, General Abacha, noted to have looted over US $\$ 4$ billion from the state treasury; investigations after his death traced the booty to about 130 banks worldwide (Harnischfeger, 2008). These regimes laid claims to discipline and value re-orientation. However, these programs were largely "admonitory and mobilisatory" (Osaghae, 2002, p. 21). They became conduits for siphoning public funds for private use that widened the gap between the state and citizens. According to Akunyili (2009a, p. 1), past re-branding efforts "ended at the mere level of intentions, except of course for the WAI," and most past efforts were a "financial jamboree" characterized by "squandering of funds."

The Heart of Africa project, which was launched in 2004 under the direction of then Minister of Information Chukwuemeka Chikelu, was a spending spree. Various road shows were organized across Europe and America. The first phase was launched 
in Washington, DC in 2006, the second in Atlanta, Georgia and Houston, Texas, in 2007, and the launch was shifted to Paris later in 2007. The image laundering project cost over 1billion (Albert, 2009). A large amount of the money was spent on foreign trips, concerts, consultancies, public relations, and radio and TV commercials to sway public opinion in favor of Nigeria.

The rhetoric of re-branding in Nigeria does not take cognizance of the reality. Rather than stemming the tide, the return to democratic rule since 1999 has led to what is seen by some as the "democratization of corruption" (Eberlein, 2006; see also Osumah, 2013). Several key officers of the state have been indicted for corrupt practices, but only a negligible few have been sanctioned. State governors who have recently been convicted of corruption and money laundering include former Edo State governor Lucky Igbinedion, his Plateau State counterpart Joshua Dariye, former Bayelsa State governor Diepriye Alamieyeseigha, and previous Delta State governor James Ibori, who was acquitted in Nigeria but later convicted and jailed in the United Kingdom (Tonwe, Ojo, \& Aghedo, 2012). According to the Economic and Financial Crime Commission, of the 36 governors who held office between 1999 and 2007, only five were free of corruption and money laundering charges; that was similar to the military era (Oyebode, 2009).

Though corruption is domestically driven, its international dimension in Nigeria is evident. A case in point is the Halliburton scandal, in which the company subsidiary KBR admitted bribing key Nigerian government officials in order to facilitate the award of a US\$6 billion Nigeria Liquefied Natural Gas construction contract. About $\$ 150$ million in bribes to Nigerians has been traced to an unnamed bank account in Zurich, Switzerland. KBR has since been investigated, convicted and fined $\$ 589 \mathrm{~m}$ in the United States (Halliburton: \$150m, 2009). However, despite the fact that Nigerians who perpetrated the crime are already well known, the state has not been able to press charges against them because the list included three former heads of state and other "big men" (see Table 1). This culture of impunity makes nonsense of any re-branding or anti-graft stance.

A culture of corruption has been entrenched in which public perception of the state as belonging to no one in particular is widespread. This lends credence to the thriving informal structures. As a result, there is more concern about competing for the "national cake" than about how to increase it. Despite Nigeria's bid to use re-branding to attract foreign investment, the illicit capital outflow from the country is monumental. Recently, Washington-based Global Financial Integrity reported that between 1970 and 2008, illicit capital outflow from Nigeria and some other African states was \$854bn (about 128.27trn); Nigeria led other countries with $\$ 89.5$ bn followed by Egypt (\$70.5bn). Illicit outflows from the region outpaced official development assistance into the 
Table 1. Alleged Payments in the Halliburton Bribery Scandal

\begin{tabular}{|c|c|c|}
\hline Year & Alleged amount (US\$) & Suspected beneficiary \\
\hline 1994-1995 & $40,000,000$ & Gen. Sani Abacha \\
\hline $1996-1998$ & $2,500,000$ & Chief Dan Etete \\
\hline 1996-1998 & 75,000 & M.D. Yusuf \\
\hline March/June 1998 & $1,120,000$ & $\begin{array}{l}\text { Grety Overseas UK } \\
\text { Riser Brothers }\end{array}$ \\
\hline 1998 & $1,887,000$ & Abulkadir Abacha \\
\hline 1999-2000 & $37,500,000$ & $\begin{array}{l}\text { Gen. Abdulsalami Abubakar } \\
\text { Chief Don Etiebet }\end{array}$ \\
\hline March 1999 & 600,000 & $\begin{array}{l}\text { Prince N.A. Bayero } \\
\text { Glosmer Int. (Risers Brothers) }\end{array}$ \\
\hline March 1999 & 290,000 & Edith Unuigbe \\
\hline March 1999 & 600,000 & $\begin{array}{l}\text { Zertasha Malik } \\
\text { Grety Overseas (Risers Brothers) }\end{array}$ \\
\hline $1999-2000$ & 195,000 & $\begin{array}{l}\text { Messr Shinkafi and Aliyu } \\
\text { Glosmer Int. (Risers Brothers) }\end{array}$ \\
\hline 2001-2002 & $74,000,000$ & $\begin{array}{l}\text { Chief Olusegun Obasanjo } \\
\text { Atiku Abubakar } \\
\text { Gaius Obaseki } \\
\text { Funsho Kupolokun }\end{array}$ \\
\hline $2001-2002$ & $5,000,000$ & Bodunde Adeyanju \\
\hline 2001-2002 & $11,700,000$ & $\begin{array}{l}\text { Ibrahim Aliyu } \\
\text { Urban Shelter } \\
\text { Intercellular }\end{array}$ \\
\hline 2001-2002 & $3,108,675$ & M.G. Bakare \\
\hline Total & $178,575,675$ & \\
\hline
\end{tabular}

Source: Ajaero (2010, p. 42).

region by a ratio of 2 to 1 (Shobiye, 2010). The situation is so pervasive that even relatives and clients of those in powerful positions pressure them to enrich themselves illegally so that the wealth will trickle down to the relatives and clients in a moral economy of reciprocity and neo-patrimonialism (Joseph, 1987; see also Okecha, 2009). A corruption-normalizing nomenclature has thus emerged. Nigerians discuss "corruption openly, disdain it and yet indulge in it" (Smith, 2007). At the same time, corruption when revealed is sometimes met with heavy condemnation.

Economically, the merchants of re-branding face a Herculean task. Dependence on oil rents has vitiated the economy and hindered a people-centered development. The rentier mentality has practically made the ordinary Nigerians to be at the service of the 
Table 2. Poverty by Region, Nigeria

\begin{tabular}{|c|c|c|c|c|c|c|}
\hline & 1980 & 1985 & 1992 & 1996 & 2004 & 2010 \\
\hline Nationwide & 28.1 & 46.3 & 42.7 & 65.6 & 54.4 & 69 \\
\hline \multicolumn{7}{|l|}{ Sector } \\
\hline Urban & 17.2 & 37.8 & 37.5 & 58.2 & 43.2 & 61.8 \\
\hline Rural & 28.3 & 51.4 & 66.0 & 69.3 & 63.3 & 73.2 \\
\hline \multicolumn{7}{|c|}{ Geopolitical zone } \\
\hline South-south & 13.2 & 45.7 & 40.8 & 58.2 & 35.1 & 63.8 \\
\hline South-east & 12.9 & 30.4 & 41.0 & 53.5 & 26.7 & 67 \\
\hline South-west & 13.4 & 38.6 & 43.1 & 60.9 & 43.0 & 59.1 \\
\hline North-central & 32.2 & 50.8 & 46.0 & 64.7 & 67.0 & 67.5 \\
\hline North-east & 35.6 & 54.9 & 54.0 & 70.1 & 72.2 & 76.3 \\
\hline North-west & 37.7 & 52.1 & 36.5 & 77.2 & 71.2 & 77.7 \\
\hline
\end{tabular}

Source: British Council (2012, p. 10).

economy as the politico-military power elite manipulates neo-liberal agendas and programs (Amuwo, 2009). The huge sums realized from the country's rich natural resources have "brought about increasing poverty, widening inequality, vast unemployment, a loss of agricultural self-sufficiency, little growth in manufacturing capacity, waste, and malfeasance" (Rotberg, 2004, p. 9). Table 2 summarizes rising poverty trends across the country, especially in the troubled northern region.

Simon Anholt, a UK-based expert, in his 2008 national brand index, ranked Nigeria 49th out of 50 measured against exports, governance, culture, people and tourism, immigration and investments (cited in Akunyili, 2009b). The World Bank rated Nigeria 125th out of 183 economies in its 2010 Doing Business Report (Realities of Vision 20:2020, 2010). The apparatus of governance for the delivery of order and peace as well as development have largely been run aground, leaving the elite to misappropriate public funds, which has inevitably spurred a wave of insurgency (Harnischfeger, 2008).

In the energy sector, demand outstrips supply. The hope of a strong energy sector to at least equate supply with demand by 2009 did not materialize. The promise of the Yar'Adua administration to increase the country's electricity generation capacity from about 3,000 megawatts to 6,000 in 2009 could not be achieved despite the investment of over $\$ 2$ billion (Electricity generation, 2009). The energy sector deserves to be considered a national emergency as less than 40 percent of 140 million Nigerians have access to electricity; there is an installed capacity of only 6,113 MW and a demand for 
Table 3. Teacher Shortages around the World

\begin{tabular}{|c|c|c|c|c|c|}
\hline Country & $\begin{array}{l}\text { Teaching } \\
\text { staff } \\
\text { in } 2009\end{array}$ & $\begin{array}{l}\text { Teaching } \\
\text { staff needed } \\
\text { in } 2015\end{array}$ & $\begin{array}{l}\text { Absolute } \\
\text { change } \\
\text { in stock }\end{array}$ & $\begin{array}{c}\text { Average } \\
\text { annual } \\
\text { change (\%) }\end{array}$ & $\begin{array}{l}\text { Total } \\
\text { recruitment } \\
\text { including } \\
\text { attrition }\end{array}$ \\
\hline Bermuda & 600 & 700 & 100 & 3.88 & 300 \\
\hline Burkina Faso & 39,000 & 85,200 & 46,200 & 13.92 & 62,800 \\
\hline Cameroon & 72,300 & 91,000 & 18,700 & 3.90 & 42,600 \\
\hline Central African Republic & 6,400 & 20,100 & 13,700 & 20.97 & 17,000 \\
\hline Chad & 27,400 & 59,600 & 32,200 & 13.80 & 43,800 \\
\hline Code d'Ivoire & 56,600 & 99,300 & 42,700 & 9.83 & 64,400 \\
\hline Congo & 10,400 & 17,200 & 6,800 & 8.68 & 10,600 \\
\hline Democratic Republic of the Congo & 274,500 & $3,722,000$ & 97,700 & 5.21 & 191,500 \\
\hline Djibouti & 1,600 & 3,200 & 1,600 & 12.03 & 2,200 \\
\hline Equatorial Guinea & 3,400 & 5,100 & 1,700 & 6.94 & 2,900 \\
\hline Eritrea & 7,800 & 21,500 & 13,700 & 18.43 & 17,400 \\
\hline Ethiopia & 234,200 & 379,400 & 145,200 & 8.37 & 231,900 \\
\hline Gambia & 6,400 & 8,400 & 200 & 4.64 & 4,200 \\
\hline Guinea & 31,800 & 48,400 & 16,600 & 7.25 & 28,000 \\
\hline Liberia & 22,300 & 30,900 & 8,700 & 5.64 & 16,400 \\
\hline Mali & 38,400 & 62,800 & 24,400 & 8.55 & 38,700 \\
\hline Mozambique & 82,800 & 130,700 & 48,000 & 7.92 & 78,300 \\
\hline Niger & 40,000 & 86,100 & 46,100 & 13.62 & 63,000 \\
\hline Nigeria & 466,800 & 688,200 & 221,400 & 6.68 & 387,000 \\
\hline Occupied Palestinian Territories & 14,100 & 20,000 & 5,800 & 5.92 & 10,700 \\
\hline Pakistan & 465,300 & 605,700 & 140,300 & 4.49 & 296,600 \\
\hline Rwanda & 33,200 & 48,700 & 15,500 & 6.61 & 27,300 \\
\hline Senegal & 47,700 & 67,500 & 19,800 & 5.97 & 36,500 \\
\hline Serbia & 17,400 & 28,600 & 11,100 & 8.58 & 17,600 \\
\hline Sudan & 123,600 & 179,400 & 55,800 & 6.40 & 99,300 \\
\hline Uganda & 168,400 & 218,100 & 49,700 & 4.40 & 106,100 \\
\hline United Republic of Tanzania & 157,200 & 248,600 & 91,400 & 7.94 & 149,000 \\
\hline Zambia & 48,100 & 75,300 & 27,200 & 7.77 & 44,800 \\
\hline
\end{tabular}

Source: Global teacher shortage $(2011$, p. 3). 
over 10,000 MW (Ojo \& Idehen, 2011; Okhonmina, 2009; Tallapragad, Pattilo, \& Adebusuyi, 2008). Similarly, over US $\$ 8$ billion has been spent on the Ajaokuta Steel Company without a single steel product resulting (Maier, 2000). The dream of the nation at 50 being one of the 20 strongest global industrial economies, as expressed in Nigeria's Vision 20:2020 appears to have suffered a major setback. The inability to deliver on energy promises is seen by citizens as a metaphor for government's failure. Some social writers related a general sense of helplessness from insecurity and the perennial electricity crisis that have resulted in low productivity from unemployment, bankruptcy, or the relocation of hundreds of firms involved in production and services to other African states such as Ghana, Benin, Togo, and South Africa (Ojo \& Idehen, 2011).

Even the educational sector has not been spared from the dire consequences of Nigerian state fragility. The university system, which was highly rated in the Commonwealth of Nations until the 1970s and 1980s, has become a citadel of "education without learning," owing largely to poor funding and incessant strikes. For example, all public universities in the country were shut down for nearly four months in 2009 as a result of a strike by the Academic Staff Union of Nigerian Universities and other unions in response to the government's failure to keep to the agreement it earlier entered with the unions regarding pay and conditions of service. Many poorer African countries have better educational indices than Nigeria because of the acute shortage of teachers (see Table 3).

Disorder and violence are present in every part of Nigeria, and though the motives seem to differ, they are often related to politics and economics. The fragility of public institutions involving the state security apparatus makes political manipulation of primordial cleavages and sentiments profitable to "entrepreneurs of violence," leading the country to be characterized by a history of conflicts which often employ ethnicity and religion as a smokescreen for personal interests. In northern Nigeria, dominated by the Hausa and Fulani, from the Maitatsine riot of 1982 through the sharia conflicts of the 1990s to the Boko Haram, which emerged in 2012 as the second deadliest terror group in the world after Afghanistan's Taliban, and the recent Jos crisis, which has claimed over 3,000 lives, the volatile mixture of politicized religion and ethnicity continues to wreak havoc on lives and property, developments that re-branding fails to contend with (Aghedo \& Osumah, 2012). Between 1999 and 2002, sectarian violence orchestrated largely by youths in northern Nigeria resulted in the loss of over 8,000 lives (Reno, 2004). Some Nigerians subscribe to the re-branding motto, yet the occasional negative interjections as in the cases of the Jos crisis from the middle belt, and the Ijebu-Ife violence that resulted in the death of hundreds of people in January 2010, are bad news occurring at regular intervals that portray Nigeria as a victim of incoherent governance. 
Besides the secessionist Biafran War of 1967-1970 by the Igbo tribe in the east, social conflict organized by ethnic militias such as the Bakassi Boys, and the Movement for the Actualization of the Sovereign State of Biafra has remained a hallmark of eastern Nigeria (Aghedo, 2011). There is an elision of this sort of self-determination found in the Niger Delta region, where agitation for resource control and self-determination by oil-bearing ethnic minorities in southern Nigeria have led to a "petro-insurgency" and criminal violence by both state forces and youth militias (Watts, 2007). A cartel has been implicated in fuelling this youth rebellion and low-intensity conflict. It is alleged that the people who run the oil bunkering cartel are among Nigeria's top political "godfathers"- hence the inability to bring them to justice, which could lead the country into another civil war because of the huge political and economic influence they wield: the "industry makes up to $£ 30 \mathrm{~m}(\$ 60 \mathrm{~m})$ a day" (Nigeria, 2008, p. 17613).

Western Nigeria, dominated by the Yorubas, is not spared ethno-religious and political instability, as shown by the perennial Ife-Modakeke conflict, the June 12, 1993 uprising, and the Oodua People's Congress crisis, among others (Ukeje \& Adebanwi, 2008). Some of these communal rivalries date back to the 1800s, yet they still assume violent dimensions and find expression in daily living. On Christmas 2009, the Muslim fundamentalist Abdul Farouk Abdulmutallab further soiled Nigeria's image abroad when he attempted to blow up an American airliner over Detroit. With this sensational entry of a Nigerian into the international terrorist scene, the re-branding project became even more difficult.

Nigeria's growing insecurity is exacerbated by easy access to light weapons. In addition to entering through the country's porous borders, weapons also disappear from the state's armory from time to time, and soldiers who served in peacekeeping operations in Sierra Leone and Liberia are reported to have "brought back large quantities of pistols and $\mathrm{AK}$ rifles bought at very ridiculous rates from rebels to sell at very high prices in Nigeria" (Reno, 2004, p. 234). These weapons often find their way into the hands of conflict perpetrators who use them to wreak havoc. For example, as many as 74,064 cases of murder, manslaughter, suicide, and rape were recorded in Nigeria in two years alone, according to a police estimate (Nigeria records, 2010). The security crisis in Nigeria is fuelled by large-scale corruption within the internal security apparatus, especially the police force, which is poorly funded, trained, and equipped (Osumah \& Aghedo, 2010).

These cases of institutional decay plus the high level of unemployment have a serious negative impact on the people. Poverty and human rights violations resulting from state's inability to discharge its responsibilities to the citizenry have been cited as some of the major drivers of illegal immigration and human trafficking in the country (Awah, 2009). The UK High Commission in Nigeria recently donated a fraud-detection 
machine and other items to the special Fraud Unit of the Nigeria Police Force to help the police tackle forgery in visa applications. Already, the Commission has meted derogatory and unilateral punishment in an effort to place a 10-year ban on applicants who submit forged documents. In the last quarter of 2009, over 15,000 Nigerian youths were repatriated for various offences, mainly violation of immigration laws (UK deports 400, 2009). Some desperate Nigerian youths resort to criminality as a survival strategy, which has complicated the poor image of the country.

For several years, Nigeria has remained a source, transit area, and destination for human trafficking despite efforts by the United Nations, European Union (EU), and International Labour Organization to stem the tide. One such effort was the re-launch of anti-trafficking cooperation between these groups and Nigeria on June 29, 2010 in Abuja. This project is funded by a 220 million ( $\$ 1.2$ million) grant from the EU. According to the head of the EU delegation in Nigeria, it is hoped that the project "will contribute to the fight against trafficking of human beings from Nigeria to Europe by improving prosecution, protection and re-integration of victims of trafficking as well as prevention of this phenomenon" (Obayuwana, 2010, p. 80). Though these anti-trafficking efforts have resulted in the re-classification of Nigeria as a Tier 1 country, the International Labour Organization has estimated that of the 12.3 million people globally trafficked into forced labor, 660,000 of them are in sub-Saharan Africa, over 130,000 are trafficked within the continent, and Nigeria is one of the highest contributors (Obayuwana, 2010; Akpomera, 2009).

Perhaps the scourge of the effort to promote Nigeria's good name is the notorious "advance fee fraud." Some of the country's criminal networks have acquired global notoriety in areas beyond oil bunkering including human and drug trafficking and Internet fraud (Bach, 2004). According to a US Secret Service estimate, Nigerian Internet scams (known locally as 419) yield their perpetrators several million dollars yearly, and the losses the United States incurred as result of these scams amounted to $\$ 5$ billion in the 1990s (Smith, 2007; Zook, 2007; Glickman, 2005). This figure may have since trebled.

The great expectations of the people that these social ills would abate with Nigeria's return to democracy have nearly been dashed owing to bad governance. The do-or-die politics of the power elite has given rise to pseudo democracy in which criminal tactics are deployed to win elective positions. Between 2007 and 2010, 12 governors were removed from office by the judiciary for election fraud. The 2007 general elections provoked over 7,000 petitions, and several of these petitions were still pending in court three months before the general election four years later (Graft, 2010). This "mandate theft" (Abutudu \& Obakhedo, 2009, p. 235) infuriates the masses and makes nonsense of Nigeria's claim to democratization and the rule of law, yet it is not 
addressed by the advocates of re-branding.

These internal contradictions are also not helped by the politics of the international mass media, which compounds Nigeria's image crisis. For several years, Nigeria has been demonized internationally, and clashes manipulated between southern and northern Nigeria. For example, a foreign news agency tried to manipulate the Organization of Islamic Conference crisis in order to cause a civil war in Nigeria (Kukah, 2007, p. 14). The international conspiracy against Nigeria has been well noted. For example, former UN Secretary General Boutrous Boutrous-Ghali once remarked that he had "never seen a country as lied against as Nigeria" (cited in Kukah, 2007, p. 15).

This international calumny has been going on for years. The British media coverage of the 1967-1970 Nigerian civil war was so biased that a critical study at the time concluded that it "was not an honourable era in British journalism: the news was often incorrect and misleading" (Akinyemi, 1972, p. 424). International media politics sways public opinion against African countries. In a recent survey, Lader (2007, p. 3) found that newspapers are the core source of information for $47 \%$ of UK citizens. Another study showed that " $80 \%$ of the British public strongly associates the developing world with doom-laden images of famine, disaster and Western aid" (VSO, 2001, p. 3). A study of the US media also concluded that the coverage of Africa is "one-dimensional ... relies on stereotypes ... lacks sufficient context [and is] predominantly negative in context" (Wall, 2007, p. 162, cited in Scott, 2009, p. 533).

Nigeria is poorly portrayed even in movies. One example is The Informant, a movie about the Archer Daniels Midland fraud case, in which the main character was duped by a Nigerian advanced-fee fraud. Also, Nigeria's image was not helped in two recent American television series, The Philanthropist (filmed mainly in South Africa) and Castle, in which the country was ridiculed as a nation of kidnappers and voodoo worshippers, respectively (For a similar but scholarly treatment of the effect of voodoo on Nigerian image, see Dijk, 2001). Although re-branding strives to counter these negative perceptions, how it intends to pursue this goal beyond putting up billboards is yet to be seen, as bad news from international media outlets and governments continues to go unchallenged.

International media politics notwithstanding, Nigeria's image crisis is largely selfinflicted. In a globalized world, events in one area will inevitably be reported to the rest of the world. Obviously, the state is unable to discharge many of its statutory functions, including ensuring order, guaranteeing welfare, minimizing corruption, and regulating people's usage of criminality as a survival strategy, thereby exposing the state to unfavorable media reports. The implication of these contradictions and social pathologies arising from the fragility of the Nigerian state is the erosion of the country's credibility both at home and abroad. Sadly, these stark realities are not taken into account by the 
leaders of Nigeria's re-branding effort, leaving the project grappling with symptoms rather than the root cause of the disease.

\section{CONCLUSION}

This article has assessed Nigeria's re-branding initiative of showcasing the good and the beautiful while papering over the bad and the ugly, including the more fundamental problems of state restructuring. Re-branding in the context of state fragility and the prebendalization politics of disorder assumes significance in the context of weak institutions involving a duality of order and disorder that allows formal and informal structures of governance to coexist. Spoils politics allows transparent governance and the national image to be sacrificed on the altar of parochial agendas. The value system is abased and citizens' morale eroded. Hence, a journalistic blitz directed at image repair becomes an exercise in futility.

While re-branding is a brilliant policy idea, its formulation, planning, and execution are totally wrong. As shown by this analysis, re-branding is not a matter of name, image, logo, and advertisement alone. Countries are judged by what they do, not just what they say. This article has suggested that dysfunctional states in Africa with colonial legacies of divide and rule are still serving as a model for development from which emerging leaders have yet to extricate themselves. This model undermines the state and its institutions, which results in weak and fragile states. Re-branding without changing attitudes and values, ensuring law and order, providing welfare and public infrastructure, and a commitment to democracy and the rule of law amounts to window dressing and an exercise in self-delusion that is doomed to fail. This has implications for national development.

Re-branding success will likely be measured by the extent to which the state's democratic institutions respond to the "entrepreneurs of violence" to counter impunity and stem prebendalization politics. State fragility has led to image erosion by inherent contradictions that amount to self-sabotage which a whitewash style of re-branding fails to contend with. The social distrust that emerges from state-citizen relations also fuels these internal contradictions, which undermine the integrity and image of the country and which even well-intentioned re-branding rather than socio-economic renaissance has failed to alter. To ensure effective re-branding of Nigeria, a serious political restructuring and attitudinal change must be crafted by both the government and the governed. The current inordinate emphasis on private rather than public interests in state dealings needs to be minimized. 


\section{REFERENCES}

Abutudu, M., \& Obakhedo, N. 2009. Mandate theft and retrieval: The 2007 governorship elections in Edo State. In J. Ibrahim \& O. Ibeanu (eds.), The 2007 Nigerian elections and subversion of popular sovereignty. Lagos: Centre for Democracy and Development.

Aghedo, I. 2011. Conflict management and peace-building. In E.O.S. Iyamu \& L.I. Salami (eds.), Peace Studies and Conflict Resolution. Benin City: Otoghagua Ent.

Aghedo, I. 2013. Winning the war, losing the peace: Amnesty and the challenges of post-conflict peace-building in the Niger Delta, Nigeria. Journal of Asian and African Studies, 48(3): 256-278.

Aghedo, I., \& Osumah, O. 2012. The Boko Haram uprising: How should Nigeria respond? Third World Quarterly, 33(5): 853-869.

Ajaero, C. 2010, May 17. The real Halliburton story. Newswatch.

Akinyemi, B, 1972. The British press and the Nigerian civil war. African Affairs (71): 408-426.

Akpomera, E, 2009. A critical evaluation of the Nigerian policy on human trafficking. Nigerian Journal of Politics and Public Policy, 5(1-2): 48-63.

Akunyili, D. 2009a. Remarks at the corporate Nigeria breakfast meeting with the minister of information and communications, Abuja, April 23.

Akunyili, D. 2009b. Speech delivered by the honourable minister of information and communications at the launch of the global database of Nigerians in diaspora, February 21.

Akunyili, D. 2009c. The time is now. Speech delivered by the honourable minister of information and communications at the launch of the re-branding Nigeria campaign and unveiling of a new national slogan and logo in Abuja, March 17.

Alao, D. 2009, May 25. 10 years of democracy: Eventful, eventful, eventful. Nigerian Compass.

Albert, R. 2009. Clapping with a finger: A rethink of the re-branding Nigeria' project. In Albert Olawale I. (ed.) Praxis of political concepts and clichés in Nigeria's Fourth Republic: Essays in honour of Dr. Mu'azu Babangida Aliyu. Ibadan: Bookcraft.

Allen, C. 1999. Warfare, endemic violence and state collapse in Africa. Review of African Political Economy, 26(81): 367-384.

Amuwo, A. 2009. The political economy of Nigeria's post-military elections, 19992007. Review of African Political Economy, 119: 37-61.

Anholt, S. 1998. Nation-brands of the twenty-first century. Journal of Brand Management, 
5(6): 395-406.

Arrighi, G. 2002. The African crisis: World systemic and regional aspects. New Left Review, 15(May/June).

Awah, I. M. 2009. Human rights violation: A perspective on women trafficking. Nigerian Journal of Social Studies, 12(2): 156-164.

Bach, C. D. 2004. Nigeria: Towards a country without a state? Paper presented on Nigeria's: Maximising pro-poor growth-regenerating the socio-economic database, organized by the Overseas Development Institute in collaboration with the Nigeria Economic Summit Group, London, June 16-17.

Bamiduro J. A., \& Aremu, M. A. 2012. Assessment of the need for and effectiveness of the re-branding in Nigeria. International Journal of Management and Administrative Sciences, 1(4): 11-22.

Barr, M. 2012. Nation branding as nation building: China's image campaign. East Asia, 29(1): 81-94.

Bayart, J.-F., Ellis, S., \& Hibou, B. 1999. The criminalization of the state in Africa. Oxford: James Currey.

British Council. 2012. Gender in Nigeria report 2012: Improving the lives of girls and women in Nigeria, issues, policies, action (2nd edition).

Bryant, R. L. 2005. Nongovernmental organizations in environmental struggles: Politics and the making of moral capital in the Philippines. New Haven and London: Yale University Press.

Chabal, P., \& Daloz, J. P. 1999. Africa works: Disorder as political instrument. Oxford: James Currey.

Collier, P. 2000. Doing well out of war: An economic perspective. In M. Berdal \& D.M. Malone (eds.), Greed and grievance: Economic agendas in civil wars. London: Lynne Rienner.

Collier, P. 2007. The bottom billion: Why the poorest countries are failing and what can be done about it. Oxford: Oxford University Press.

Committee on Re-branding. 2009, March 7. Technical report of the ad-hoc committee on re-branding Nigeria.

De Oliveira, R. S. 2007. Oil and politics in the Gulf of Guinea. London: Hurst.

Dijk, van R. 2001. Voodoo on the doorstep: Young Nigerian prostitutes and magic policing in the Netherlands. Africa, 71(4): 558-586.

Dumont, R. 1988. False start in Africa. London: Earthscan.

Eberlein, R. 2006. On the road to the state's perdition? Authority and sovereignty in the Niger Delta, Nigeria. Journal of Modern African Studies, 44(4): 573-596.

Electricity generation: Between claims and reality. 2009, November 13. Nigerian Compass. 
Falola, T., \& Heaton, M. 2008. A history of Nigeria. New York: Cambridge University Press.

Foley, F. 2009. Reforming counterterrorism: Institutions and organizational routines in Britain and France. Security Studies, 18: 435-478.

Gilmore, F. 2002. A country - can it be repositioned? Spain-the success story of country branding. Journal of Brand Management, 9(4-5): 281-293.

Glickman, H. 2005. The Nigerian '419' advance fee scams: Prank or peril? Canadian Journal of African Studies, 39(3): 462-489.

Global teacher shortage threatens progress in education. 2011, October 13. Punch.

Graft, judiciary and election petitions. 2010, July 5. Punch.

Halliburton: \$150m bribe money found in Swiss Bank. 2009, April 9. Daily Champion. Harnischfeger, J. 2008. Democratization and Islamic law: The sharia conflict in Nigeria. Frankfurt and New York: Campus Verlag.

Herbst, J. 2000. State and power in Africa. Princeton, NJ: Princeton University Press.

Ihonvbere, O. J. 1994. The irrelevant state: Ethnicity and quest for nationhood in Africa. Ethnic and Racial Studies, 17(1): 42-60.

Joseph, R. 1987. Democracy and prebendal politics in Nigeria: The rise and fall of the Second Republic. Ibadan: Spectrum Books.

Joseph, R. 2002. War, state-making, and democracy in Africa. In R. M. Beissinger \& Y. Crawford (eds.), Beyond state crisis? Post-colonial Africa and post-soviet Eurasia in comparative (pp. 240-262). Washington, DC: Woodrow Wilson Centre Press.

Keen, D. 2006. Endless wars: Hidden functions of the war on terror. London: Pluto/ Michigan University Press.

Kukah, H. K. 2007. Nigeria, democracy and Africa's challenges. Third convocation lecture delivered at Benson Idahosa University, November 29.

Lader, O. 2007. Public attitudes towards development. London: DFID.

Lewis, P. 1996. From prebendalism to predation: The political economy of decline in Nigeria. Journal of Modern African Studies, 34(1): 79-103.

Maass, P. 2009. Crude world: The violent twilight of oil. London: Penguin Books.

Maier, K. 2000. This house has fallen: Nigeria in darkness. London: Penguin Books.

Mamdani, M. 2002. Citizen and subject: Contemporary Africa and the legacy of late colonialism. Ibadan: John Archers.

Ministry of Information. 2009. Frequently asked questions about the re-branding project. Abuja: Federal Ministry of Information.

Moloney, K. 2000. The rise and fall of spin: Changes of fashion in the presentation of UK politics. Journal of Public Affairs, 1(2): 124-135.

Muzellec, L., \& Lambkin, M. C. 2006. Corporate rebranding: The art of destroying 
transferring and recreating brand equity? European Journal of Marketing, 40(7/8): 803-824.

Nduka, O. 2006. The roots of African underdevelopment and other essays. Ibadan: Spectrum Books.

Nigeria. 2008. Africa Research Bulletin, July: 17613.

Nigeria records 74,064 murders, other cases in 2 years-report. 2010, November 21. Sunday Punch.

Nwajiaku-Dahou, K. 2009. Heroes and villains: Ijaw nationalist narratives of the Nigerian civil war. Africa Development, 34(1): 47-67.

Obayuwana, O. 2010, August 9. UN, ILO move to stop human trafficking in Nigeria. Guardian.

Ojo, G. U., \& Idehen, R. 2011. Institutional inefficiency and PHCN-consumer sabotage: The case of energy crisis in Benin City and implications for national development. Benin Journal of Sciences, 19(1-2): 207-220.

Okecha, S. 2009. Leadership, ethics and accountability in office. In Aghayere and Iyoha (eds.), Ethics, standard and accountability in governance. Ekpoma: Ambrose Alli University, Governance and Development Institute.

Okhonmina, S. 2009. The implications of power outage for manpower productivity, economic development and national security: The Nigerian experience. Igbinedion Journal of Diplomacy and Strategy, 1(1): 193-200.

Okolie, A. 2010. Nigeria's role in peacekeeping in Africa: ECOMOG, Chad, Liberia, and Sierra Leone. In A. M. Jega and J. W. Farris (eds.), Nigeria at fifty: Contributions to peace, democracy and development. Abuja: Shehu Musa Yar'Adua Foundation.

Onovo, O. 2009. Combating the crimes of armed robbery and kidnapping in the southeast and south-south zones of Nigeria: Strategies, challenges and prospects. Igbinedion Journal of Diplomacy and Strategy, 1(1): 12-21.

Osaghae, E. E. 2002. Crippled giant: Nigeria since independence. Ibadan: John Archers. Osaghae, E. E. 2007. Fragile states. Development in Practice, 17(4): 691-699.

Osumah, O. 2013. Tonic or toxic? The state, neopatrimonialism, and anticorruption efforts in Nigeria. Korean Journal of Policy Studies, 28(1): 111-134.

Osumah, O., \& Aghedo, I. 2010. The open sore of a nation: Corruption complex and internal security in Nigeria. African Security, 3(3): 137-147.

Osumah, O., \& Aghedo, I. 2011 Who wants to be a millionaire? Nigerian youth and the commodification of kidnapping. Review of African Political Economy, 38(128): 277-287.

Oyebode, O. 2009, May 21. I was offered $\$ 15$ million bribe by ex-governor-Ribadu. Punch. 
Oyefusi, A. 2008. Oil and the probability of rebel participation among youths in the Niger Delta of Nigeria. Journal of Peace Research, 45(4): 539-555.

Peel, M. 2005. Crisis in the Niger Delta: How failures of transparency and accountability are destroying the region. Chatham House Briefing Paper AFP BP 05/02. London: Chatham House.

Pottier, J. 2010. Representation of ethnicity in the search for peace: Ituri, Democratic Republic of Congo. African Affairs, 109(434): 23-50.

Realities of Vision 20:2020 in blurred economy. 2010, August 1. Daily Independent.

Reno, W. 1998. Warlord politics and African states. Boulder: Lynne Rienner.

Reno, W. 2004. The roots of sectarian violence and its cure. In I. R. Rotberg (ed.), Crafting the new Nigeria: Confronting the challenges (pp. 219-238). London: Lynne Rienner.

Reviewing Nigeria's role in peace operations. 2010, August 10. Punch.

Rotberg, I. R. 2004. Trouble Nigeria: Great opportunities, tough challenges. In I. R. Rotberg (ed.), Crafting the new Nigeria: Confronting the challenges (pp. 1-16). London: Lynne Rienner.

Scammell, M. 1995. Designer politics: How elections are won. London: Macmillan.

Scott, M. 2009. Marginalised, negative or trivial? Coverage of Africa in UK Press. Media, Culture and Society, 31(4): 533-557.

Shobiye, H. 2010, March 31. Illicit capital flight: Nigeria, other African nations lost N128.27trn in 38 years-report. Punch.

Smith, D. J. 2007. A culture of corruption: Everyday deception and popular discontent in Nigeria. Princeton, NJ: Princeton University Press.

Stobart, P. 2002. Creating powerful brands. In Business: The ultimate resource. London: Bloomsbury.

Svensson, I. 2007. Fighting with faith: Religion and conflict resolution in civil wars. Journal of Conflict Resolution, 51(6) 930-949.

Szondi, G. 2008. Public diplomacy and nation branding: Conceptual similarities and differences, in discussion papers in diplomacy. Copenhagen: Netherlands Institute of International Relations.

Tallapragad, V. S. N., Pattilo, C., \& Adebusuyi, B. S. 2008. Nigeria's power sector: Opportunities and challenges. In P. Collier, C. C. Soludo, \& C. Pattillo (eds.), Economic policy options for a prosperous Nigeria (pp. 301-327). New York: Palgrave Macmillan.

Tonwe, D. A., Ojo, G. U., \& Aghedo, I. 2012. Spoils politics and environmental struggle in the Niger Delta region of Nigeria. Inkanyiso Journal of Human and Social Sciences, 4(1): 37-48.

UK deports 400 Nigerian prisoners. 2009, February 21. Vanguard. 
Ukeje, C., \& Adebanwi W. 2008. Ethno-nationalist claims in southern Nigeria: Insights from Yoruba and Ijaw nationalism since the 1990s. Ethnic and Racial Studies, 31(3): 563-591.

Utomi, P. 2004. Nigeria as an economic powerhouse: Can it be achieved? In I. R. Robert (ed.), Crafting the new Nigeria: Confronting the challenges. London: Lynne Rienner.

VSO. 2001. Live aid legacy. London: VSO.

Watts, M. 2007. Petro-insurgency or criminal syndicate? Conflict and violence in the Niger Delta. Review of African Political Economy, 34(114): 637-660.

Young, C. 2004. The end of post colonial state in Africa? Reflections on changing African political dynamics. African Affairs, 103(410): 23-49.

Zook, M. 2007. Your urgent assistance requested: The intersection of 419 spam and new networks of imagination. Ethics, Place and Environment, 10(1): 65-88. 